\title{
Supplements of the manuscript: modeling inorganic
}

\section{carbon dynamics in the Seine River continuum in France}

Audrey Marescaux, Vincent Thieu, Nathalie Gypens, Marie Silvestre, Josette Garnier

\section{S1: List of state variables for the RIVE model}

\begin{tabular}{|c|c|c|}
\hline GROUP * & VARIABLE & DESCRIPTION \\
\hline & Q & mean discharge during the 10 day period in $\mathrm{m}^{3} \mathrm{~s}^{-1}$ \\
\hline \multirow{4}{*}{ PHY } & DIA & diatom biomass in $\mathrm{mgC}^{-1}$ \\
\hline & GRA & green algae (chlorophyceae) biomass in $\mathrm{mgC}^{-1}$ \\
\hline & CYA & cyanobacteria biomass in $\mathrm{mgC}^{-1}$ \\
\hline & MES & mineral suspended solid in $\mathrm{mg}^{-1}$ \\
\hline \multirow{6}{*}{ NUTS } & NO3 & nitrates in $\mu \mathrm{mol} 1^{-1}$ \\
\hline & NH4 & ammonium in $\mu \mathrm{mol} \mathrm{l}^{-1}$ \\
\hline & PO4 & phosphates in $\mu \mathrm{mol} \mathrm{1} 1^{-1}$ \\
\hline & PIT & total inorganic phosphorus in $\mu \mathrm{molP}{ }^{-1}[* *]$ \\
\hline & SIO & dissolved silica in $\mu \mathrm{mol}^{-1}$ \\
\hline & OXY & dissolved oxygen in $\mu \mathrm{mol} \mathrm{l}^{-1}$ \\
\hline \multirow[t]{2}{*}{$\mathrm{ZOO}$} & ZOR & rotiferan-like zooplankton in $\mathrm{mgC}^{-1}$ \\
\hline & $\mathrm{ZOC}$ & 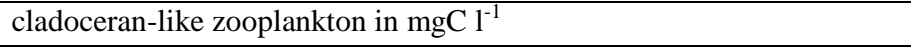 \\
\hline \multirow{4}{*}{ BACT } & BAG & heterotrophic bacteria $>1 \mu$ in $\mathrm{mgC}^{-1}$ \\
\hline & BAP & heterotrophic bacteria $<1 \mu$ in $\mathrm{mgC}^{-1}$ \\
\hline & NIT & ammonium oxidizing nitrifying bacteria in $\mathrm{mgC}^{-1}$ \\
\hline & NAT & nitrite oxidizing nitrifying bacteria in $\mathrm{mgC}^{-1}$ \\
\hline \multirow{7}{*}{$\mathrm{OC}$} & DOC1 & rapidly biodegradable dissolved organic matter in $\mathrm{mgC}^{-1}$ \\
\hline & DOC2 & slowly biodegradable dissolved organic matter in $\mathrm{mgC}^{-1}$ \\
\hline & DOC3 & refractory dissolved organic matter in $\mathrm{mgC}^{-1}$ \\
\hline & POC1 & rapidly biodegradable particulate organic matter in $\mathrm{mgC}^{-1}$ \\
\hline & POC 2 & slowly biodegradable particulate organic matter in $\mathrm{mgC}^{-1}$ \\
\hline & POC 3 & refractory particulate organic matter in $\mathrm{mgC}^{-1}$ \\
\hline & DSS & low molecular weight directly assimilable organic substrates in $\mathrm{mgC}^{-1}$ \\
\hline \multirow{13}{*}{ Benthic } & SIB & biogenic non-living particulate (amorphous) silica in $\mu \mathrm{mol} \mathrm{l}^{-1}$ \\
\hline & BOC1 & benthic (deposited) rapidly biodegradable organic matter in $\mathrm{gC} \mathrm{m}^{-2}$ \\
\hline & $\mathrm{BOC} 2$ & benthic (deposited) slowly biodegradable organic matter in $\mathrm{gC}^{-2}$ \\
\hline & BOC3 & benthic (deposited) refractory organic matter in $\mathrm{gC}^{-2}$ \\
\hline & BPI & benthic (deposited) inorganic phosphorus in mmolP $\mathrm{m}^{-2}$ \\
\hline & BBS & benthic (deposited) biogenic silica in $\mathrm{mmol} \mathrm{m}^{-2}$ \\
\hline & BFE & benthic (deposited) faecal bacteria in $1000 \mathrm{~m}^{-2} \mathrm{l}^{-1}$ \\
\hline & SED & deposited inorganic material in $\mathrm{g} \mathrm{m}^{-2}$ \\
\hline & FEL & free living faecal bacteria in $\mathrm{nb} \mathrm{l}^{-1}$ \\
\hline & FEA & attached faecal bacteria in $\mathrm{nb} \mathrm{l}^{-1}$ \\
\hline & $\mathrm{N} 2 \mathrm{O}$ & nitrous oxide in $\mu \mathrm{mol} \mathrm{l}^{-1}$ \\
\hline & NO2 & nitrite in $\mu \mathrm{mol} \mathrm{l}^{-1}$ \\
\hline & $\mathrm{CH} 4$ & methane in $\mu \mathrm{mol} \mathrm{l}^{-1}$ \\
\hline \multirow{3}{*}{ IC } & $\mathrm{CO} 2(* * *)$ & Carbon dioxide in $\mathrm{mgC}^{-1}$ \\
\hline & $\mathrm{TA}(* * *)$ & Total alkalinity in $\mu \mathrm{mol}^{-1}$ \\
\hline & $\mathrm{DIC}(* * *)$ & Dissolved inorganic carbon in $\mathrm{mgC}^{-1}$ \\
\hline
\end{tabular}

$(*)$ "Group" refer to generic group name provided in Erreur ! Source du renvoi introuvable. in this paper 
(**) An instantaneous equilibrium is considered for adsorption of ortho-phosphate on MES, so that PIT is the only primary state variable to be considered.

(***) New state variable added in the RIVE model

All biomasses (DIA, GRA, CYA, BAG, BAP, NIT, NAT, ZOR, ZOC) as well as organic matter pools (DOC 1 $2-3$, POC 1-2-3, BOC 1-2-3) are considered to have constant massic $\mathrm{C}: \mathrm{N}$ ratios, namely $\mathrm{C} / \mathrm{N}=7$ 


\section{S2: Modeling objects of the Seine basin}

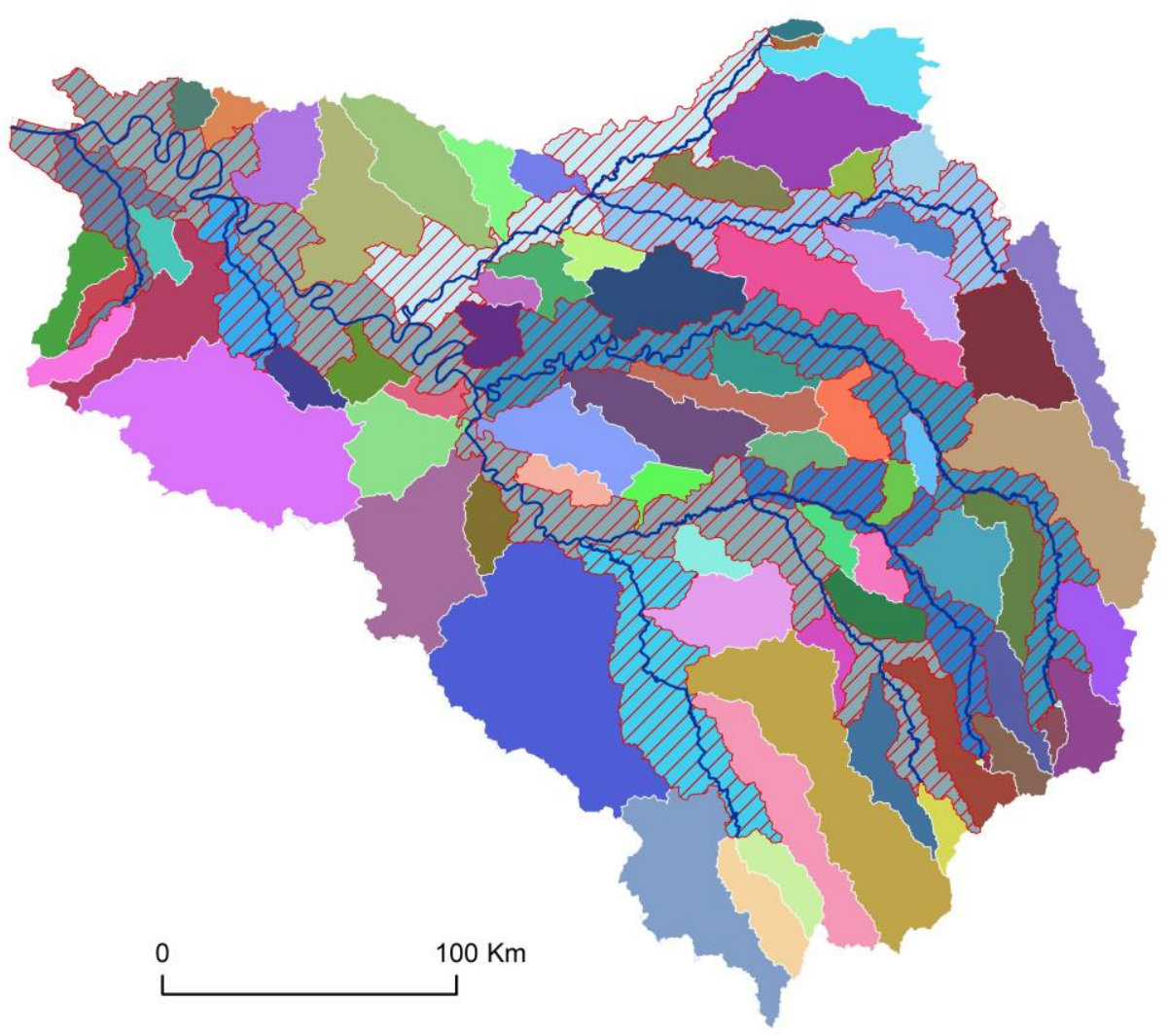

Fig. S1. PyNuts-Riverstrahler modeling objects. Eight "Axis" objects (main river branches, mapped with red hatching) and 72 "basin" objects (upstream tributaries connected to "axis" objects). 


\section{S3: Description of the inorganic carbon module implemented in pyNuts-Riverstrahler}

\subsection{The carbonate systems}

The major dissolved forms of the carbonate system are $\mathrm{CO}_{2}(\mathrm{aq})$ aqueous carbon dioxide, $\mathrm{H}_{2} \mathrm{CO}_{3}$ (aq) carbonic acid, $\mathrm{HCO}_{3}{ }^{-}(\mathrm{aq})$ bicarbonate ion, $\mathrm{CO}_{3}{ }^{2-}$ (aq) carbonate ion.

$$
\begin{gathered}
\mathrm{CO}_{2}(g) \rightleftharpoons \mathrm{CO}_{2}(a q) \\
\mathrm{CO}_{2}(a q)+\mathrm{H}_{2} \mathrm{O}(a q) \rightleftharpoons \mathrm{H}_{2} \mathrm{CO}_{3}(a q) \rightleftharpoons \mathrm{HCO}_{3}^{-}(a q)+\mathrm{H}^{+}(a q) \\
\mathrm{HCO}_{3}^{-}(a q) \rightleftharpoons \mathrm{CO}_{3}^{2-}(a q)+\mathrm{H}^{+}(a q)
\end{gathered}
$$

The acid dissolution constants from the second and the third equations are, respectively:

$$
\begin{gathered}
K_{1}=\frac{\left[\mathrm{H}^{+}\right]\left[\mathrm{HCO}_{3}^{-}\right]}{\left[\mathrm{CO}_{2}\right]} \\
K_{2}=\frac{\left[\mathrm{H}^{+}\right]\left[\mathrm{CO}_{3}^{2-}\right]}{\left[\mathrm{HCO}_{3}^{-}\right]} \\
\text {with } \mathrm{pK}=-\log K
\end{gathered}
$$

\subsection{Carbonate system as a function of DIC}

Carbonate dissociation can be determined by total inorganic carbon.

$$
\mathrm{DIC}=\left[\mathrm{CO}_{2}\right]+\left[\mathrm{HCO}_{3}^{-}\right]+\left[\mathrm{CO}_{3}^{2-}\right]
$$

With the insertion of [4] and [5] in [7], DIC becomes:

$$
\mathrm{DIC}=\frac{\left[\mathrm{H}^{+}\right]\left[\mathrm{HCO}_{3}^{-}\right]}{K_{1}}+\left[\mathrm{HCO}^{3-}\right]+\frac{\left[\mathrm{HCO}_{3}^{-}\right] \mathrm{K}_{2}}{\left[\mathrm{H}^{+}\right]}
$$




$$
\leftrightarrow\left[\mathrm{HCO}_{3}^{-}\right]=\frac{\mathrm{DIC}}{\frac{\left[\mathrm{H}^{+}\right]}{K_{1}}+\frac{K_{2}}{\left[H^{+}\right]}+1}
$$

and with $\left[\mathrm{HCO}_{3}^{-}\right]$, we can calculate $\left[\mathrm{CO}_{3}^{2-}\right]$ and $\left[\mathrm{CO}_{2}\right]$ with [8] and [9].

$$
\begin{gathered}
{\left[\mathrm{CO}_{2}\right]=\frac{\left[\mathrm{H}^{+}\right]}{K_{1}} \frac{D I C}{\frac{\left[H^{+}\right]}{K_{1}}+\frac{K_{2}}{\left[H^{+}\right]}+1}} \\
{\left[\mathrm{CO}_{3}^{2-}\right]=\frac{K_{2} C}{\left[H^{+}\right]} \frac{D I C}{\frac{\left[H^{+}\right]}{K_{1}}+\frac{K_{2}}{\left[H^{+}\right]}+1}}
\end{gathered}
$$

\subsection{The dissociation constants of carbonic acid}

According to Millero et al. (2006), Harned and Scholes (1941), Harned et al. (1943) the dissociation constants of carbonic acid (molar concentration unit) are calculated as:

$$
\begin{aligned}
& p K_{1}=-126.34048+\frac{6320.813}{T_{K}}+19.568224 * \ln \left(T_{K}\right) \\
& p K_{2}=-90.18333+\frac{5143.692}{T_{K}}+14.613358 * \ln \left(T_{K}\right)
\end{aligned}
$$

where $T_{k}$ is the water temperature in Kelvin ( $\left.{ }^{\circ} \mathrm{K}\right)$.

and:

$$
\begin{aligned}
& K_{1}=10^{-p K_{1}} \\
& K_{2}=10^{-p K_{2}}
\end{aligned}
$$

Eq. 15 


\section{4. $\mathrm{pH}$ calculation}

In the pyNuts-Riverstrahler model, $\mathrm{pH}$ had not yet been calculated. In the inorganic carbon module, we added the calculation of $\mathrm{pH}$ derived from Culberson (1980) to calculate the speciation of carbonate (Eqs. 9-11).

$$
D I C_{\text {conv }}=\frac{D I C}{12 r h o} 10^{6}
$$

$\mathrm{DIC}_{\text {conv }}$ (conversion from $\mathrm{mgC} \mathrm{L}^{-1}$ to $\mu \mathrm{mol} \mathrm{kg}{ }^{-1}$ ), where rho $\left(\mathrm{kg} \mathrm{m}^{-3}\right.$ ) is the water density from'Millero and Poisson, 1981)

$$
\begin{aligned}
& \text { Xdiss }=\left(1-\frac{B o r 0}{C A}\right) \cdot K_{b}+\left(1-\frac{D I C_{c o n v}}{C A}\right) \cdot K_{1} \\
& \text { Ydiss }=\left(1-\frac{B o r 0+D I C_{c o n v}}{C A}\right) \cdot K_{1} \cdot K_{b}+\left(1-2 \cdot \frac{D I C_{c o n v}}{C A}\right) \cdot K_{1} \cdot K_{2} \\
& \text { Zdiss }=\left(1-\frac{B o r 0+2 \cdot D I C_{\text {conv }}}{C A}\right) \cdot K_{1} \cdot K_{2} \cdot K_{b} \\
& a C u l b=\frac{\left(X_{d i s s^{2}}-3 . Y d i s s\right)}{9} \\
& b C u l b=\frac{-\left(2 X \text { diss }^{3}-9 . X \text { diss.Ydiss }+27 . Z \text { diss }\right)}{54} \\
& \text { phyCulb }=\cos \left(\frac{b C u l b}{\left(a C u l b^{3}\right)^{0.5}}\right) \\
& {\left[\mathrm{H}_{3} \mathrm{O}^{+}\right]=2 \cdot a C u l b^{0.5} \cdot \cos \left(\frac{\text { phyCulb }}{3}\right)-\frac{X \text { diss }}{3}} \\
& p H=-\log _{10}\left[H_{3} O^{+}\right]
\end{aligned}
$$

where Bor0 is the total dissolved boron concentration that can generally be ignored in freshwaters (Emiroglu et al., 2010). "Xdiss", "Ydiss", "Zdiss" are the coefficient of the general cubic equation. "aCulb" and "bCulb" are the zero of the general cubic equation. $\mathrm{H}_{3} \mathrm{O}^{+}$is the positive roots of the general cubic equation that can be calculated from phyCulb (where arc $\cos$ (phyCulb) is the inverse trigonometric function) (see Culberson et al. 1980).

\section{5. $\mathrm{CO}_{2}$ flux calculation}

The carbonate speciation function makes it possible to calculate the concentration in aqueous carbon dioxide $\left(\mathrm{CO}_{2}\right)$ (eq. 10). 
The flux $\left(\mathrm{gC} \mathrm{m}^{-2} \mathrm{~h}^{-1}\right)$ of $\mathrm{CO}_{2}$ at the interface of the river and the atmosphere is calculated as:

$$
F_{\mathrm{CO}_{2}}=\frac{k}{24}\left(\mathrm{CO}_{2}-\mathrm{CO}_{2} \mathrm{~atm}\right) \cdot \mathrm{rho} \cdot 10^{-3}
$$

Monthly atmospheric $\mathrm{CO}_{2}\left(\mathrm{CO}_{2} \mathrm{~atm}, \mathrm{mgC} \mathrm{L}^{-1}\right)$ was measured at Mauna Loa Observatory (Hawaii, USA) and provided by the NOAA/ESRL:

(http://www.esrl.noaa.gov/gmd/ccgg/trends/, last accessed 2018/11/05), Scripps Institution of Oceanography (scrippsco2.ucsd.edu/, last accessed 2018/11/05). Concentrations in ppm from Mauna Loa Observatory were converted to $\mathrm{mgC}^{-1}$ using solubility according to Weiss, (1974). The $\mathrm{CO}_{2}$ concentration in water $\left(\mathrm{CO}_{2}\right)\left(\mathrm{mgC} \mathrm{L}^{-1}\right)$ was calculated according to section 3.2. Carbonate system as a function of DIC". $r h o\left(\mathrm{~kg} \mathrm{~m}^{-3}\right)$ is the water density calculated by the International One Atmosphere Equation (Millero and Poisson, 1981).

The flux of $\mathrm{CO}_{2}$ depends on the gas transfer velocity $(k)$ that can be determined from the temperature-normalized gas transfer velocity $\left(k_{600}\right) . k_{600}$ is the gas transfer velocity at a water temperature of $20^{\circ} \mathrm{C}$. Parametrization related to the gas exchange used $k_{600}$ to compare systems excluding temperature's physical effect. According to Wilke and Chang (1955) and Wanninkhof (1992), the gas transfer velocity $k\left(\mathrm{~m} \mathrm{~d}^{-1}\right)$ can be calculated as:

$$
k=k_{600} \cdot \sqrt{\frac{600}{S c_{\mathrm{CO}_{2}}(T)}}
$$

$k_{600}$ is the gas transfer velocity for a Schmidt number of $600\left(\mathrm{~m} \mathrm{~d}^{-1}\right)$, and $S c_{\mathrm{CO}_{2}}(T)$ is the Schmidt number (dimensionless) calculated with the water temperature $(T)$ in Celsius $\left({ }^{\circ} \mathrm{C}\right)$ calculated as:

$$
S c_{\mathrm{CO}_{2}}(T)=1911.1-118.11 T+3.4527 T^{2}-0.04132 T^{3}
$$

For rivers less than $100 \mathrm{~m}$ wide (SO 1-5), the $\mathrm{k}_{600}$ equation used was retrieved from Alin et al. (2011): 


$$
k_{600}=\frac{13.82+0.35 v * 100}{100}
$$

where $\mathrm{k}_{600}\left(\mathrm{~m} \mathrm{~d}^{-1}\right)$ depends on $v$, the water velocity $\left(\mathrm{m} \mathrm{s}^{-1}\right)$.

In general, $\mathrm{k}_{600}$ equations for rivers of widths greater than $100 \mathrm{~m}$ require wind velocity (e.g., Chu and Jirka, 2003; Alin et al., 2011; Raymond et al., 2012a). At this stage the pyNuts Riverstrahler model does not consider the wind as an input, which would have required a much higher spatiotemporal resolution to reflect its heterogeneity in the Seine basin with the diurnal cycle affected by phenomena such as breeze (Quintana-Seguí et al., 2008). Therefore, for river widths greater than $100 \mathrm{~m}$, the $\mathrm{k}_{600}$ equation from O'Connor and Dobbins, (1958) and Ho et al. (2016), neglecting the term related to the wind, was selected (see Erreur ! Source du renvoi introuvable.):

$$
k_{600}=\frac{a \sqrt{\frac{v}{d e p t h}}}{100}
$$

where $\mathrm{k}_{600}\left(\mathrm{~m} \mathrm{~d}^{-1}\right)$ depends on $v$, the water velocity $\left(\mathrm{m} \mathrm{s}^{-1}\right)$, and the river depth $(\mathrm{m})$ and the coefficient "a". The coefficient was tested from 0 to 2 for SO6 and SO7. We found that SO6 showed a behavior near the original coefficient of 1.539 from O'Connor and Dobbins (1958) with 1.55 , and SO7 a behavior near the 0.77 proposed by and Ho et al. (2016) with 0.55 . 


\subsection{Parameters, constants and equations used in the inorganic carbon module.}

Table S1 Parameters used in the inorganic carbon module for freshwaters

\begin{tabular}{|c|c|c|c|}
\hline Parameters & Acronym & Units & Sources \\
\hline $\begin{array}{l}\text { Dissociation constants } \\
\text { of carbonic acid }\end{array}$ & $\mathrm{K}_{1}, \mathrm{~K}_{2}$ & $\mu \mathrm{mol} \mathrm{l}{ }^{-1}$ & $\begin{array}{c}\text { Harned and Scholes (1941), Harned et al. } \\
\text { (1943), } \\
\text { and, Millero et al. (2006) }\end{array}$ \\
\hline Solubility & $\mathrm{k} 0$ & $\mathrm{~mol} \mathrm{~kg} \mathrm{~atm}^{-1}$ & Weiss (1974) \\
\hline gas transfer velocity & $k$-value & $\mathrm{m} \mathrm{h}^{-1}$ & $\begin{array}{l}\text { Wanninkhof (1992), Wilke and Chang (1955) } \\
\text { Alin et al. (2011, eq. for river width inferior } \\
\text { to } 100 \mathrm{~m} \text { ) and O'Connor and Dobbins (1958) } \\
\text { updated in Ho et al. (2016), for river width } \\
\text { superior to } 100 \mathrm{~m} \text {. }\end{array}$ \\
\hline water density & Rho & $\mathrm{kg} \mathrm{m}^{-3}$ & Millero and Poisson (1981) \\
\hline $\mathrm{pH}$ & $\mathrm{pH}$ & - & Culberson (1980) \\
\hline $\begin{array}{l}\text { Apparent ionization } \\
\text { constant of boric acid }\end{array}$ & $\mathrm{Kb}$ & $\mathrm{hPa}$ & Schubert (2011) \\
\hline
\end{tabular}




\section{S4 Representation of superficial MESO water bodies}

Groundwaters are under strong anthropogenic pressures due to water withdrawn for drinking water production and pollution by agriculture. The European directive (Water Framework Directive 2000/60/CE) aims to reach the good environmental status of surface and groundwaters and has introduced the notion of groundwater bodies (French acronym: Masse d'Eau SOuterraine - MESO) (Fig. S2). These MESO units are defined by hydrogeological criteria (e.g., extent and characteristics of the geological layers, feeding area, hydraulic connection between geological layers, interaction with surface waters and associated terrestrial ecosystems, etc.) and nonhydrogeological criteria (capture or the possibility of capture; impact of pressures, potential pollution, administrative boundaries, etc.). The status and upward trends in the concentrations of any pollutant in groundwaters are monitored at the MESO scale. The Seine basin includes 48 unconfined (fully or partially) MESO units (see map), which were regrouped according to the lithology and geological ages (colors) to simplify the representation.

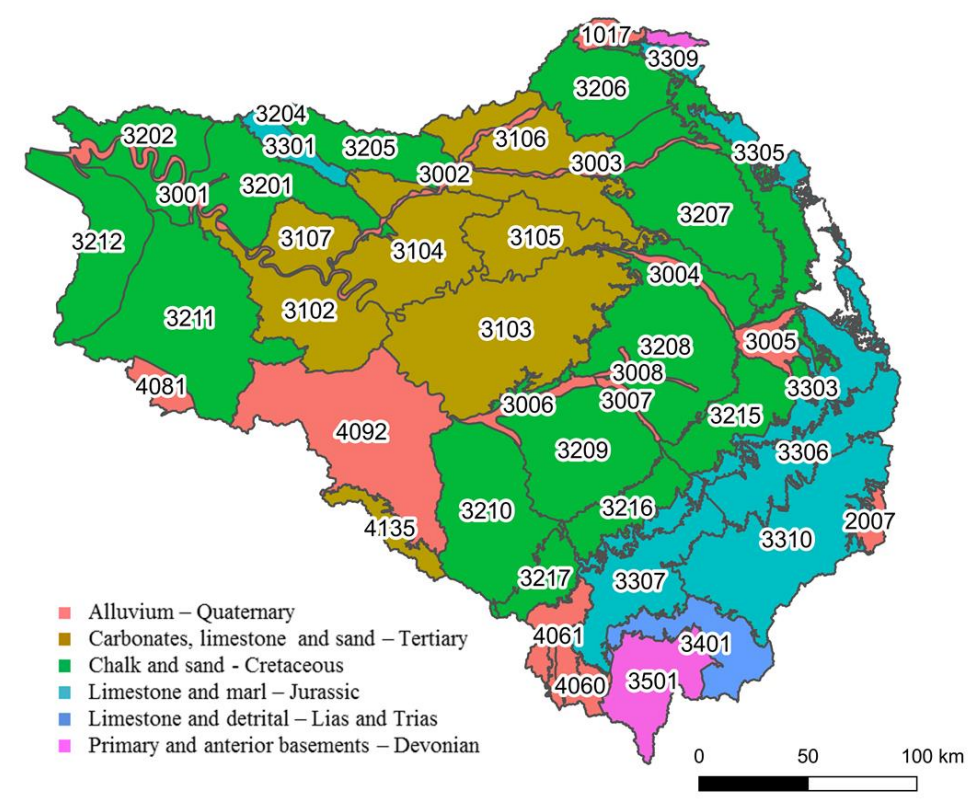

Fig. S2. Superficial MESO (Masse d'Eau SOuterraine) water bodies of the Seine basin grouped according to the lithology and geological ages 
Table S2 Mean concentrations and standard deviations of total alkalinity (TA, $\mu$ mole $\mathrm{L}^{-1}$ ) and dissolved inorganic carbon (DIC, $\mathrm{mgC} \mathrm{L}^{-1}$ ) grouped by MESO units in the Seine Basin for the 2010-2013 period.

\begin{tabular}{|c|c|c|c|c|c|}
\hline \multirow{2}{*}{ MESO code } & \multirow{2}{*}{$\begin{array}{c}\text { Dominant lithology and } \\
\text { geological age }\end{array}$} & \multicolumn{2}{|c|}{ TA $\left(\mu\right.$ mole $\left.L^{-1}\right)$} & \multicolumn{2}{|c|}{ DIC $\left(\mathrm{mgC} \mathrm{L}^{-1}\right)$} \\
\hline & & mean & $s d$ & mean & $s d$ \\
\hline 1017 & \multirow{14}{*}{ Alluvium - Quaternary } & 5113 & 388 & 79 & 3 \\
\hline 2007 & & 4454 & 671 & 75 & 7 \\
\hline 3001 & & 4030 & 1018 & 71 & 12 \\
\hline 3002 & & 5058 & 677 & 85 & 6 \\
\hline 3003 & & 5288 & 1025 & 90 & 11 \\
\hline 3004 & & 4532 & 992 & 72 & 10 \\
\hline 3005 & & 4624 & 487 & 79 & 8 \\
\hline 3006 & & 3960 & 493 & 69 & 7 \\
\hline 3007 & & 4254 & 382 & 67 & 7 \\
\hline 3008 & & 4274 & 832 & 70 & 10 \\
\hline 4060 & & 4701 & 291 & 74 & 2 \\
\hline 4061 & & 4701 & 291 & 74 & 2 \\
\hline 4081 & & 1568 & 1462 & 35 & 16 \\
\hline 4092 & & 4245 & 785 & 72 & 10 \\
\hline 3102 & \multirow{7}{*}{$\begin{array}{c}\text { carbonate, limestone and sand - } \\
\text { Tertiary }\end{array}$} & 4719 & 878 & 81 & 15 \\
\hline 3103 & & 5453 & 988 & 76 & 11 \\
\hline 3104 & & 5580 & 673 & 92 & $\overline{10}$ \\
\hline 3105 & & 5387 & 768 & 91 & 7 \\
\hline 3106 & & 5321 & 360 & 89 & 10 \\
\hline 3107 & & 5264 & 488 & 86 & 5 \\
\hline 4135 & & 3774 & 1011 & 64 & 11 \\
\hline 3201 & \multirow{16}{*}{ chalk and sand - Cretaceous } & 5264 & 488 & 83 & 4 \\
\hline 3202 & & 4574 & 546 & 76 & 6 \\
\hline 3204 & & 4831 & 389 & 81 & 1 \\
\hline 3205 & & 5192 & 470 & 83 & 5 \\
\hline 3206 & & 5134 & 576 & 83 & 7 \\
\hline 3207 & & 4268 & 941 & 70 & 11 \\
\hline 3208 & & 3911 & 866 & 64 & 10 \\
\hline 3209 & & 4169 & 680 & 69 & 8 \\
\hline 3210 & & 4669 & 590 & 75 & 6 \\
\hline 3211 & & 4173 & 801 & 67 & 10 \\
\hline 3212 & & 4713 & 401 & 77 & 4 \\
\hline 3214 & & 5172 & 941 & 87 & 12 \\
\hline 3215 & & 4394 & 1202 & 73 & 13 \\
\hline 3216 & & 4732 & 1011 & 77 & 11 \\
\hline 3217 & & 5002 & 481 & 77 & 4 \\
\hline 3218 & & 4590 & 995 & 75 & 12 \\
\hline 3301 & \multirow{8}{*}{ Limestone and marl - Jurassic } & 1660 & 346 & 41 & 5 \\
\hline 3303 & & 5120 & 467 & 82 & 6 \\
\hline 3304 & & 4939 & 265 & 78 & 4 \\
\hline 3305 & & 5236 & 971 & 88 & 12 \\
\hline 3306 & & 4629 & 754 & 77 & 8 \\
\hline 3307 & & 4907 & 585 & 80 & 6 \\
\hline 3309 & & 4938 & 365 & 81 & 4 \\
\hline 3310 & & 4454 & 671 & 75 & 7 \\
\hline 3401 & $\begin{array}{c}\text { Limestone and detrital - Lias } \\
\text { and Trias }\end{array}$ & 5053 & 699 & 82 & 8 \\
\hline 3501 & \multirow{2}{*}{$\begin{array}{c}\text { Primary and anterior basements } \\
\text { - Devonian }\end{array}$} & 765 & 228 & 25 & 4 \\
\hline 3508 & & 663 & 683 & 27 & 9 \\
\hline
\end{tabular}




\section{S5: Sampling strategy and protocol for measuring emissions from wastewater treatment plants in the Seine basin}

Table S3. Location of the sampled WWTPs. Their nominal capacity and type of treatment are retrieved from http://assainissement.developpement-durable.gouv.fr/, last accessed 2019/03/07. Measured values for TA, DIC, $\mathrm{pH}$ and $\mathrm{pCO}_{2 .}$.

\begin{tabular}{|c|c|c|c|c|c|c|c|}
\hline WWTPs & Location & $\begin{array}{c}\text { Nominal } \\
\text { capacity } \\
\text { (Inhab. Eq.) }\end{array}$ & Water treatment & $\underset{\left(\mu \mathrm{mole} \mathbf{L}^{-1}\right)}{\text { TA }}$ & $\begin{array}{c}\text { DIC } \\
\left(\mathrm{mgC} \mathrm{L}^{-1}\right)\end{array}$ & pH & $\underset{(\mathbf{p p m v})}{\mathrm{pCO}_{2}}$ \\
\hline Butry & $49^{\circ} 04^{\prime} 60 \mathrm{~N}, 2^{\circ} 12^{\prime} 00 \mathrm{E}$ & 6700 & Low load actived sludge & 5885 & 76.27 & 7.3 & 31723 \\
\hline Auvers & $49^{\circ} 04^{\prime} 00 \mathrm{~N}, 2^{\circ} 10^{\prime} 00 \mathrm{E}$ & 34,300 & $\begin{array}{c}\text { Secondary treatment, } \\
\text { denitrification, } \\
\text { dephosphatation }\end{array}$ & 3700 & 53.39 & 7.26 & 28723 \\
\hline Dammarie & $48^{\circ} 30^{\prime} 57^{\prime \prime N}, 2^{\circ} 36^{\prime} 43^{\prime \prime E}$ & 80,000 & $\begin{array}{c}\text { Secondary treatment, } \\
\text { denitrification, } \\
\text { dephosphatation }\end{array}$ & 4800 & 68.55 & 7.45 & 17268 \\
\hline Rosny & $49^{\circ} 0^{\prime} 7^{\prime \prime N}, 1^{\circ} 39^{\prime} 11^{\prime \prime E}$ & 135,417 & $\begin{array}{c}\text { Secondary treatment, } \\
\text { denitrification, } \\
\text { dephosphatation }\end{array}$ & 4500 & 55.50 & 7.4 & 18651 \\
\hline Troyes & $48^{\circ} 20^{\prime} 5^{\prime \prime} \mathrm{N}, 4^{\circ} 2^{\prime} 37^{\prime \prime} \mathrm{E}$ & 260,000 & $\begin{array}{c}\text { Secondary treatment, } \\
\text { denitrification, } \\
\text { dephosphatation }\end{array}$ & \#N/A & 86.31 & 7.4 & 29930 \\
\hline Seine Centre & $48^{\circ} 55^{\prime} 58^{\prime \prime N}, 2^{\circ} 14^{\prime} 43^{\prime \prime} \mathrm{E}$ & 800,000 & $\begin{array}{c}\text { Secondary treatment, } \\
\text { denitrification, } \\
\text { dephosphatation }\end{array}$ & 3590 & 47.44 & 8.17 & \#N/A \\
\hline $\begin{array}{l}\text { St-Thibault- } \\
\text { des-Vignes }\end{array}$ & $48^{\circ} 52^{\prime} 20^{\prime \prime} \mathrm{N}, 2^{\circ} 40^{\prime} 27^{\prime \prime E}$ & 350,000 & $\begin{array}{c}\text { Secondary treatment, } \\
\text { denitrification, } \\
\text { dephosphatation }\end{array}$ & 5660 & 73.55 & 7.40 & 15732 \\
\hline SAV & $\begin{array}{c}48^{\circ} 58^{\prime} 25^{\prime \prime} \mathrm{N} \\
2^{\circ} 09^{\prime} 56^{\prime \prime} \mathrm{E}\end{array}$ & $7,500,000$ & $\begin{array}{c}\text { Secondary treatment, } \\
\text { denitrification, } \\
\text { dephosphatation }\end{array}$ & 2915 & \#N/A & 7.91 & \#N/A \\
\hline \multicolumn{4}{|c|}{ Inputs of the model (weighted average per capacity): } & 3993 & 69.75 & & \\
\hline
\end{tabular}

Water samples were filtrated on combusted filters ( $4 \mathrm{~h}$ at $500^{\circ} \mathrm{C}$ : GF/F $0.7 \mu \mathrm{m}, 25 \mathrm{~mm}$ ), and filtrates enabled measurement of DIC and TA concentrations. Dissolved inorganic carbon was analyzed with a TOC analyzer (Aurora 1030). Nongaseous DIC analyses required acidification of the filtrated sample by adding sodium persulfate reagents $\left(100 \mathrm{~g} \mathrm{~L}^{-1}\right)$ to dissociate the carbonate in the $\mathrm{CO}_{2}$ that was detected with nondispersive infrared gas analysis (IRGA). TA ( $\mu \mathrm{mol} \mathrm{kg-1)}$ was analyzed using an automatic titrator (TitroLine ${ }^{\circledR} 5000$ ) on three 20-mL replicates of filtered water (GF/F: $0.7 \mu \mathrm{m})$, with hydrochloric acid $(0.1 \mathrm{M})$. 